DOI https://doi.org/10.30525/978-9934-26-000-1-10

\title{
ETYKA ZAWODOWA PUBLIC RELATIONS NA UKRAINIE: WYZWANIA 2019 ROKU
}

\author{
Hulaj W. W. \\ Kierownik katedry informacji międzynarodowej \\ Uniwersytet Narodowy «Politechnika Lwowska» \\ Dmytruk W. I. \\ Dyrektor \\ Hrynokh N. W. \\ Zastępca dyrektora ds. edukacyjnych \\ «Oddziat wyodrębniony \\ «Filia lwowska Kijowskiego uniwersytetu narodowego kultury i sztuki» \\ Lwów, Ukraina
}

Dwie tury wyborów prezydenckich i następne wybory parlamentarne w 2019 roku na Ukrainie wymagają kompleksowej analizy założeń, przebiegu, wyników i skutków. Pół roku po zakończeniu wyborów możemy jednak stwierdzić nowe wyzwania i możliwości dla rozwoju dziedziny public relations na Ukrainie.

Na nasze przekonanie, na podstawie wyników 2019 roku możemy mówić również o kryzysie tradycyjnego PR na Ukrainie na poziomie narzędziowym (poziom technologii), wartościowym (poziomy punktów orientacyjnych, w szczególności etycznych w prowadzeniu kampanii PR) i instytucjonalnym (poziomie zawodowej samoorganizacji specjalistów PR) .

Wybór Wołodymyra Zełenskiego Prezydentem Ukrainy w drugiej turze wyborów w dniu 21 kwietnia 2019 roku z wynikiem 73 \% głosów wyborców i pewna wygrana z $43 \%$ jego partii «Sługa ludu» na przedterminowych wyborach do Rady Najwyższej Ukrainy 21 lipca tego roku z formacją jednopartyjnej większości parlamentarnej, między innymi, wykazały nieskuteczność tradycyjnych narzędzi wyborczych, w szczególności technologii PR, i zmusiły zwrócić uwagę na rolę mediów społecznościowych w szczególności.

Coraz większa wirtualizacja i digitalizacja zakresu funkcjonowania nowoczesnego PR, w szczególności w strefie politycznej, wnosi do porządku obrad celowość tworzenia i realizacji standardów funkcjonowania zawodowych społeczności specjalistów ds. public relations.

Fragmentacja i dekoncentracja $\mathrm{w}$ różnych wymiarach środowiska zawodowego specjalistów ds. public relations na Ukrainie z jednej strony komplikuje realizację zamierzeń wdrożenia standardów etycznych, a z drugiej, pozwala artykułować różne wizje zawodu specjalisty ds. PR w ogóle i etyki PR, w szczególności. 
W ciągu ostatnich dziesięcioleci było kilka prób, aby stworzyć stowarzyszenie zawodowe, były oferowane różne opcje kodeksów specjalisty ds. public relations. Stworzenie Organizacji Publicznej «Ukraińskie Stowarzyszenie Public Relations» UAPR dało początek rozwoju zawodowej społeczności ukraińskiego PR [4, c. 89].

Ukraińskie Stowarzyszenie public relations - UAPR «ma na celu zjednoczyć wszystkich przedstawicieli branży, dla których ważny jest również własny rozwój, jak i rozwój przemysłu PR w naszym państwie zgodnie z najlepszymi standardami międzynarodowymi» [1, c. 141]. Za pozytywny krok również można uznać przyjęcie Kodeksu etyki zawodowej UAPR, który odpowiada światowym standardom.

W 2003 r. została założona Ogólnoukraińska Organizacja Społeczna «Ukraińska Liga Public Relations» (PR-Liga). Celem organizacji był rozwój usług w zakresie public relations na zasadach i podstawach Międzynarodowej Społeczności PR (IPRA). Obecnie te stowarzyszenia jednak nie prowadzą aktywnej działalności, ich strony internetowe nie są aktualizowane, a właściciele bardziej skupione są na rozwiązywaniu problemów własnej działalności gospodarczej [4, c. 89].

Tak więc, pod czas ustalania składnika zawodowo-branżowego instytucjonalizacji działalności PR powstaje szereg przeszkód: niedorozwój systemu kontroli etycznej regulacji działalności PR; brak systemu mechanizmów kontroli, ostrzegania i zapobiegania antyspołecznych, prawnie niekontrolowanych działań; niska aktywność związków, stowarzyszeń przy rozwiązaniu zadań branżowych, takich jak budowanie dialogu z innymi instytucjami społecznymi - władzą, środkami masowego przekazu itp; brak systemu ochrony przedstawicieli branży i ich interesów zawodowych; podniesienie statusu społecznego i prestiżu zawodu, jego integracja i włączenie do światowego systemu komunikacyjnego [5, c. 100].

Wszystkie te kryteria są ściśle związane z jądrem każdej instytucji społecznej - normami i wartościami.

$\mathrm{Na}$ początku lat $2010 \mathrm{z}$ inicjatywy Ogólnoukraińskiej Organizacji Społecznej «Ukraińska Liga Public Relations» zostało uruchomione opracowanie kodeksu certyfikacji specjalistów ds. public relations i środków masowego przekazu w celu utrzymania wysokich standardów profesjonalizmu i etyki zgodnie $\mathrm{z}$ zasadami demokratycznego konkurencyjnego społeczeństwa [5, c. 89-90]. Projekt jednak nigdy nie został ukończony, o czym świadczyłaby obowiązkowa certyfikacja agencji i konsultantów w zakresie komunikacji PR. Inna sprawa, że, pomimo braku jedynych dokumentów, które regulują działalność ukraińskich specjalistów w zakresie PR, pojawienie się podobnych inicjatyw świadczy o próbie ustalenia systemu norm samoregulacji, co jest ważnym krokiem na drodze do instytucjonalizacji PR na Ukrainie.

Oddzielnie skupiając się na zakresie funkcjonowania politycznego PR na Ukrainie w ogóle i wdrażaniu standardów etycznych, w szcze- 
gólności, warto zatrzymać się na projekcie «Sprzedawcy rankingów. Baza pseudosocjologów» [6], gdzie dużą wagę przywiązuje się do wykrywania pseudo PR-owców.

Wraz z właściwie socjologicznymi według nazwy organizacjami o wątpliwej reputacji osobny dział o nazwie «Ukryte specjalisty ds. PR», gdzie są krótkie biografie około 100 osób.

Analizując krytycznie próbę oceny tych lub innych specjalistów zaangażowanych do politycznego PR na Ukrainie w ostatnim czasie nie możemy nie zauważyć wyrazisty akcent na wykrycie, a tym samym stawiać pod znakiem zapytania etyczne zasady kilkadziesiąt osób, przede wszystkim wskutek ich występu na żywo na kanałach telewizyjnych nieformalnej media-grupy kuma prezydenta W. Putina i faktycznego lidera drugiej pod względem liczebności frakcji parlamentarnej «Platforma Opozycyjna «Za życie» Wiktora Medwedczuka.

Przykładem nowych instytucjonalno-proceduralnych form funkcjonowania środowiska zawodowego specjalistów ds. PR politycznego chcemy oddzielnie zatrzymać się na III Konferencji technologów politycznych i doradców politycznych, która odbyła się 7 grudnia bieżącego roku w Kijowie, stając się wystarczająco reprezentatywną imprezą komunikacji zawodowej, została przekształcona w prywatną grupę na portalu społecznościowym «Facebook», gdzie w szczególności wznoszą się pytania wypracowania wspólnych etycznych zasad działalności i ich przestrzeganie [7].

Fundamentem etycznej działalności PR jest zrozumienie istoty kategorii takich jak etyka, moralność, szacunek, zaufanie i sprawiedliwość, a także ich interpretacji filozoficznych. To właśnie te kategorie są podstawą obu kierunków kształtowania podejścia do etyki PR: kodeksów zawodowych i badań naukowców i praktyków, oraz są ich główną cechą wspólną. Różnica między badaniami naukowymi i kodeksami zawodowymi jako źródła kształtowania się podejścia do etyki PR polega na tym, że kodeksy są powołani, aby kierować działania specjalisty ds. PR przy dylematach, które powstają w praktyce, a naukowcy pracują nad stworzeniem uniwersalnych kategorii etyki public relations i podejść do niej [2, c. 153].

Zasady zachowania etycznego specjalisty ds. PR w jego relacji ze społeczeństwem, środkami masowego przekazu, społeczeństwem w ogóle a pewną grupą docelową, w szczególności, etyka relacji z klientami (zarówno obecnymi, jak i byłymi i potencjalnymi), poprawność i moralność postępowania $w$ środowisku informatycznym, właściwie z informacją i jej źródłami, tolerancja, uprzejmość, rzetelność postępowania z kolegami i kolegów po «fachu», moralny stosunek do zawodowego honoru i reputacji - to nie jest pełna lista, ale podstawowy zakres zagadnień będących obiektami oświetlenia $\mathrm{w}$ zawodowych kodeksach etyki PR, powstał na podstawie świadomości i dyskusji praktyki zawodowej [3, c. 131].

Osobnym aspektem etyki PR są manipulacje w środkach komunikacji. Właśnie ostatnie podczas kampanii prezydenckiej i parlamentarnej 
2019 roku na Ukrainie stały się prawdziwymi wyzwaniami dla środowiska zawodowego public relations.

W tym kontekście istotne i przydatne jest, w szczególności, polskie doświadczenie opracowania i wdrażania norm profesjonalizmu w Polsce.

\section{Література:}

1. Березенко В. В. Теоретичні та науково-практичні розробки в сфері паблік рилейшнз (2002-2006 рр.). Наукові записки [Української академії друкарства]. 2014. № 4. С. 140-145.

2. Грицюта Н. М., Геселева К. О. Компаративний аналіз зарубіжних концепцій етики PR. Держава та регіони. Серія: Соџіальні комунікації. 2017. № 3. C. 150-154.

3. Грицюта Н. M. Професійна етика PR-діяльності: сутність поняття, принципи. Держава та регіони. Серія: Соціальні комунікації. 2014. № 4. С. 130-135.

4. Киричок А. П. Зв'язки з громадськістю як соціальний інститут. Обрії друкарства. 2015. № 1. С. 87-94.

5. Кравченкова Г. М. Паблік рілейшинз як соціальний інститут: нормативний і організаційний підхід. Соиіальні технологї: актуальні проблеми теорії та практики. 2013. Вип. 58. С. 95-103.

6. Продавці рейтингів. База псевдосоціологів. Режим доступу: https://texty.org.ua/d/socio/

7. III Конференція політтехнологів та політичних консультантів України. Режим доступу: https://www.facebook.com/groups/IIIConference 